Volume 1 Nomor 1, November 2020: h. 24 - 32

P-ISSN: 2722-4465, E-ISSN: 2746-8151

Creative Commons Attribution-NonCommercial 4.0 International

\title{
Penerapan Hukum dalam Pemutusan Hubungan Kerja dan Kebijakan Bank Terhadap Debitur yang Terdampak Pandemi Covid- 19
}

\author{
Taun $^{1 *}$, Ananda Nugraha ${ }^{2}$
}

1,2, Fakultas Hukum Universitas Singaperbangsa Karawang, Karawang, Indonesia.

*E-mail: taun@fh.unsika.ac.id

\begin{tabular}{|c|c|}
\hline Dikirim: 02/06/2020 & Dipublikasi: 30/10/2020 \\
\hline Info Artikel & Abstract \\
\hline \multirow[t]{2}{*}{$\begin{array}{l}\text { Keywords: } \\
\text { Fixed Term Work } \\
\text { Agreement; Termination of } \\
\text { Employment; Indonesian } \\
\text { Banking; Corona Virus } \\
\text { Disease-19. }\end{array}$} & $\begin{array}{l}\text { Corona Virus Disease-19 (COVID-19) in Indonesia has a bad impact } \\
\text { on the country's economy, banking, even the survival of the } \\
\text { Community / Worker. The purpose of this study is to examine and } \\
\text { analyze the legal consequences of employers who terminate the } \\
\text { employment of PKWT workers who are affected by COVID-19 and the } \\
\text { Bank's policy to set aside credit agreements for debtors affected by the } \\
\text { termination of employment. This study uses a normative juridical } \\
\text { research method with a statute approach and a case approach. The } \\
\text { results show that the government's efforts to maintain public safety and } \\
\text { maintain economic stability, in the spread of COVID-19, can affect the } \\
\text { performance and capacity of micro, small and medium business debtors, } \\
\text { thus potentially disrupting banking performance and financial system } \\
\text { stability which can affect economic growth. Therefore, to encourage } \\
\text { optimization of the banking intermediation function, maintain } \\
\text { financial system stability, and support economic growth, an economic } \\
\text { stimulus policy is needed as a counter cylical effect of the spread of } \\
\text { COVID-19. }\end{array}$ \\
\hline & Abstrak \\
\hline $\begin{array}{l}\text { Kata Kunci: } \\
\text { Perjanjian Kerja Waktu } \\
\text { Tertentu, Pemutusan } \\
\text { Hubungan Kerja, } \\
\text { Perbankan Indonesia; } \\
\text { Corona Virus Disease-19. }\end{array}$ & $\begin{array}{l}\text { Corona Virus Disease-19 (COVID-19) di Indonesia berdampak } \\
\text { buruk bagi perekonomian negara, perbankan, sampai } \\
\text { keberlangsungan hidup Masyarakat/Pekerja sekalipun. Tujuan } \\
\text { dari penelitian ini mengkaji dan menganalisi akibat hukum } \\
\text { terhadap pengusaha yang melakukan pemutusan hubungan } \\
\text { kerja pekerja PKWT yang terdampak COVID-19 dan kebijakan } \\
\text { Bank dalam mengenyampingkan perjanjian kredit terhadap } \\
\text { debitur yang terkena pemutusan hubungan kerja tersebut. } \\
\text { Penelitian ini menggunakan metode penelitian yuridis } \\
\text { normative dengan pendekatan perundang-undangan (statute } \\
\text { aproach) dan pendekatan kasus (case aproach). Hasil penelitian } \\
\text { menunjukan bahwa upaya pemerintah untuk menjaga } \\
\text { keselamatan masyarakat dan menjaga kestabilan ekonomi, } \\
\text { dalam penyebaran COVID-19 dapat mempengaruhi kinerja dan } \\
\text { kapasitas debitur usaha mikro,kecil dan menengah, sehingga } \\
\text { berpotensi mengganggu kinerja perbankan dan stabilitas sistem } \\
\text { keuangan yang dapat mempengaruhi pertumbuhan ekonomi. }\end{array}$ \\
\hline
\end{tabular}


DOI:

10.47268/ballrev.v1i1.422
Oleh karena itu, untuk mendorong optimalisasi fungsi intermediasi perbankan, menjaga kestabilan sistem keuangan, dan mendukung pertumbuhan ekonomi diperlukan kebijakan stimulus perekonomian sebagai counter cylical dampak penyebaran COVID-19.

\section{Pendahuluan}

Indonesia memasuki masa kritis pandemi Covid-19 (Pesulima \& Hetharie, 2020: 280), Pandemi COVID-19 sangat berpengaruh besar di Indonesia, dimana Indonesia merupakan salah satu negara yang mempunyai populasi manusia yang sangat padat, dengan kata lain Indonesia mempunyai sumber daya manusia/tenaga kerja yang sangat banyak, sehingga merupakan sesuatu yang berpengaruh besar untuk melakukan pembangunan. Namun dampak dari Pandemi COVID-19 yang semakin menekan berbagai pihak baik pemerintah, masyarakat dan perusahaan sekalipun dimana hal ini menjadikan penetapan dan kebijakan pemerintah serta perusahaan menjadi seusatu yang mendesak dan konkrit.

Pandemi Covid-19 membuat kesehatan dan Ekonomi Indonesia menjadi ambang diantara keduanya, sebagai salah satu kebijakan mengenai Pemerintah ini ialah agar kesehatan di nomor satukan yang kemudian diikuti perekonomian sehingga Masyarakat/Tenaga Kerja menjadi pelaksana atau korban, dengan ini perusahaan melakukan pemutusan hubungan kerja secara sepihak dengan tenaga kerjanya, karena pastinya berbagai sektor dan faktor yang membuat beberapa atau banyak perusahaan mengalami penurunan perkonomian secara sigmifikan, alasan yang mendasar ini yang menjadi penyebabnya. Maka akan timbul pengangguran yang justru berdampak buruk dan memberatkan perekonomian Indonesia. Apabila Pandemi ini terus berangsur angsur, disinilah peran pemerintah sangat diharapkan oleh masyarakat.

Pandemi Covid-19 berdampak terhadap hampir seluruh bidang termasuk ketenagakerjaan, kesulitan keuangan yang dihadapi perusahaan berimplikasi terhadap munculnya tindakan pemutusan hubungan kerja (PHK) sebagai alasan efisiensi maupun alasan force majure (Randi, 2020: 119). Pasal 1 angka 15 Undang-Undang Nomor 13 Tahun 2003 untuk selanjutnya disebut dengan Undang-Undang Ketenagakerjaan menyebutkan : "bahwa hubungan kerja adalah hubungan antara pengusaha dengan Karyawan/buruh berdasarkan perjanjian kerja yang mempunyai unsur Karyawan, upah dan perintah". Berdasarkan pengertian hubungan kerja tersebut jelaslah bahwa hubungan kerja sebagai bentuk hubungan hukum lahir atau tercipta setelah adanya perjanjian kerja antara Karyawan dengan pengusaha (Husni, 2010: 63).

Hubungan kerja yang dimaksud dalam Undang-Undang Ketenagakerjaan adalah suatu perikatan kerja yang bersumber dari undang-undang. Ketentuan perjanjian kerja yang ada hubungannya kerja atau ketenagakerjaan bukan merupakan bagian dari hukum perjanjian, oleh karena itu dikatakan bahwa ketentuan perjanjian kerja bukan hukum pelengkap. Hal ini berarti ketentuan perjanjian kerja bersifat memaksa artinya ketentuan perjanjian kerja dalam hukum ketenagakerjaan tersebut wajib ditaati dan dipatuhi (Rusli, 2004: 70), dalam ketentuan Undang-Undang Ketenagakerjaan, perjanjian kerja dibedakan menjadi dua yakni Perjanjian Kerja Waktu Tertentu (PKWT) dan perjanjian Kerja Waktu Tidak Tertentu (PKWTT) (Ferianto \& Darmanto, 2009: 3). 
Pasal 57 ayat (2) Undang-Undang Ketenagakerjaan, Perjanjian Kerja Waktu Tertentu (PKWT) adalah perjanjian bersyarat, antara lain dipersyaratkan bahwa perjanjian harus dibuat tertulis dan dibuat dalam bahasa Indonesia, dengan ancaman bahwa tidak dibuat secara tertulis dan tidak dibuat dengan bahasa Indonesia dinyatakan sebagai Perjanjian Kerja Waktu TidakTertentu (PKWTT). Pasal 1 ayat (1) Keputusan Menteri Tenaga Kerja dan Transmigrasi Nomor KE 10004 Tentang Ketentuan Pelaksanaan Perjanjian ke waktu tertentu (PKWT) adalah perjanjian kerja antara Karyawan/buruh dengan pengusaha untuk mengadakan hubungan kerja dalam waktu tertentu atau untuk Karyawanan tertentu yang bersifat sementara" (Ferianto \& Darmanto, 2009: 71).

Ada permasalahan yang timbul dalam PKWT ketika Pandemi COVID-19 adalah saat perjanjian masih berjalan, ternyata salah satu pihak (perusahaan) mengakhirinya sehingga merugikan pihak yang lain (tenaga kerja). Dalam pratik, perjanjian kerja memuat klausula tentang hal-hal yang menyebabkan berakhirnya perjanjian sehingga pada saat salah satu pihak merasa ada pelanggaran dari perjanjian tersebut, maka secara sepihak melakukan pengakhiran hubungan kerja dengan dasar klausula perjanjian kerja tersebut. Hal ini jelas telah sesuai dengan ketentuan Pasal 61 ayat (1) Undang-Undang Ketenagakerjaan sehingga apabila ada pelanggaran PKWT yang menyebabkan berakhirnya perjanjian harus terlebih dahulu melalui proses Penyelesaian Perselisihan Hubungan Industrial. Kecuali, berakhirnya perjanjian kerja itu disebabkan karena Karyawan meninggal dunia, berakhirnya jangka waktu perjanjian kerja, atau force maejeure seperti bencana alam, kerusuhan sosial, dan gangguan keamanan (Ferianto \& Darmanto, 2009: 5).

Berdasarkan Pasal 62 Undang-Undang Ketenagakerjaan menyebutkan bahwa Apabila salah satu pihak mengakhiri hubungan kerja sebelum berakhirnya jangka waktu yang ditetapkan dalam perjanjian kerja waktu tertentu, atau berakhirnya hubungan kerja bukan karena ketentuan sebagaimana dimaksud dalam Pasal 61 ayat (1), pihak yang mengakhiri hubungan kerja diwajibkan membayar ganti rugi kepada pihak lainnya.

Pada kenyataannya banyak sekali Pengusaha yang melakukan pemutusan hubungan kerja sebelum masa kontrak berakhir. Contohnya seseorang diperkerjakan oleh PT tertentu sebagai operator produksi dengan status Pegawai Tidak Tetap dan/atau Pegawai Perjanjian Kerja Waktu Tertentu yang didasarkan atas selesainya Karyawanan tertentu. Karyawan dikontrak pada tanggal 01 September 2019 sampai dengan tanggal 31 Agustus 2020 namun, pada bulan Januari 2020 Karyawan di PHK. Pemutusan hubungan kerja ini dilakukan dan atas dasar surat yang diterbitkan oleh Pengusaha yang bersangkutan.

\section{Metode Penelitian}

Penelitian ini akan disusun dengan menggunakan penelitian yuridis normatif, yaitu penelitian kaidah-kaidah atau norma-norma dalam hukum positif (Ibrahim, 2006: 295). Yuridis normatif, yaitu pendekatan yang menggunakan konsepsi legis positivis. Konsep ini memandang hukum identik dengan norma-norma tertulis yang dibuat dan diundangkan oleh lembaga atau pejabat yang berwenang. Konsepsi ini memandang hukum sebagai suatu sistem normatif yang bersifat mandiri, tertutup dan terlepas dari kehidupan masyarakat yang nyata. Penelitian ini menggunakan pendekatan perundang-undangan (statute aproach) dan pendekatan kasus (case aproach). Pendekatan perundang-undangan digunakan untuk mengetahui keseluruhan peraturan hukum khususnya hukum tentang ketenagakerjaan. Metode pendekatan ini bertujuan untuk mempelajari penerapan hukum dan akibat hukum tentang Pengusaha yang terpaksa melakukan pemutusan hubungan kerja karena terdampak Pandemi COVID-19. 


\section{Hasil dan Pembahasan}

\subsection{Akibat Hukum Terhadap Pengusaha yang Melakukan Pemutusan Hubungan Kerja Pekerja PKWT Terdampak COVID-19}

Hubungan kerja ini perusahaan dengan pekerja membuat sebuah perjanjian, dalam hal ini disebut dengan perjanjian buruh. Perjanjian buruh ini diatur dalam KUHPerdata (Herman et al., 2020: 161). Pada dasarnya dalam hukum perdata setiap orang diberi kebebasan untuk membuat perjanjian baik dari segi bentuk maupun muatan, selama tidak melanggar ketentuan perundang-undangan, kesusilaan, kepatutan dalam masyarakat (lihat Pasal 1337 KUHPerdata). Setelah perjanjian timbul dan mengikat para pihak, hal yang menjadi perhatian selanjutnya adalah tentang pelaksanaan perjanjian itu sendiri, akibat timbulnya perjanjian kerja tersebut, maka para pihak terikat di dalamnya dituntut untuk melaksanakannya dengan baik layaknya undang-undang bagi mereka. Hal ini dinyatakan Pasal 1338 KUHPerdata, yaitu:

a) Perjanjian yang dibuat oleh para pihak secara sah berlaku sebagai undang-undang bagi mereka yang membuatnya.

b) Perjanjianperjanjianperjanjianperjanjian yang telah dibuat tidak dapat ditarik kembali kecuali adanya kesepakatan dari para pihak atau karena adanya alasan yang dibenarkan oleh undang-undang.

c) PerjanjianPerjanjianPerjanjianPerjanjian harus dilaksanakan dengan itikat baik.

Adanya hubungan kerja maka lahirlah perjanjian kerja (Sinaga, 2018: 362), salah satu ketentuan yang sangat mendasar dalam Undang-undang Ketenagakerjaan Nomor 13 Tahun 2003 adalah pengaturan hubungan kerja. Hal ini menjadi sangat penting, karena perjanjian kerja merupakan titik awal dari adanya hubungan kerja. Perjanjian kerja sebagaimana yang tercantum dalam Pasal 7 disebutkan bahwa apabila setelah masa pelatihan berakhir maka pihak kedua tidak diperbolehkan mengundurkan diri. Selain itu, dalam Pasal 59 ayat (4) Undang-undang Nomor 13 Tahun 2003 disebutkan: Perjanjian kerja waktu tertentu yang didasarkan atas jangka waktu tertentu dapat diadakan paling lama 2 (dua) tahun dan hanya boleh diperpanjang 1 (satu) kali untuk jangka waktu paling lama (satu) tahun.

Pandemi covid-19 berpengaruh dalam pelaksanaan perjanjian, dimana telah terjadi penurunan kemampuan ekonomi seseorang/akibat lain sehingga berpengaruh terhadap pelaksanaan perjanjian bagi seseorang (Aminah, 2020: 650). Dampak COVID-19 ini membuat banyak dari pengusaha perusahaan melakukan Pemutusan Hubungan Kerja secara terpaksa. Wakil Ketua Umum Kadin Indonesia Shinta W Kamdani mengatakan, ada beberapa alasan perusahaan melakukan pemutusan hubungan kerja (PHK) selama masa penyebaran Virus Corona (Covid-19) (Shinta W Kamdani, 2020); Pertama, lemahnya permintaan pasar, termasuk akibat kebijakan Pembatasan Sosial Berskala Besar (PSBB); Kedua adalah keterbatasan bantuan modal. Ketiga keterbatasan cash-flow terutama untuk membiayai gaji tenaga kerja yang merupakan komponen tertinggi dari biaya perusahaan; Namun demikian, tanpa stimulus tambahan dari pemerintah maka cepat atau lambat kinerja perusahaan akan lebih tertekan lagi. "Memang sudah ada beberapa stimulus yang pemerintah keluarkan, hanya saja realisasinya tidak lancar dan diperlukan jumlah stimulus yang lebih besar saat ini," sambungnya. Kadin sendiri sebelumnya telah memperhitungkan adanya penambahan stimulus sebesar Rp1.600 triliun guna menjaga roda perekonomian. Jumlah tersebut hampir empat kali lebih besar dari nilai anggaran yang pemerintah gelontorkan, yakni Rp405,1 triliun;Ketiga,“Tidak hanya dari segi demand (market, sektor riil) namun juga memperhatikan stimulus dari segi supply yaitu perbankan, terutama untuk 
dapat melancarkan penyaluran modal dengan bunga yang rendah bagi sektor-sektor riil yang terdampak,"

Pokok-pokok pengaturan POJK Stimulus Dampak COVID-19 antara lain:

a) POJK ini berlaku bagi BUK, BUS, UUS, BPR, dan BPRS.

b) Bank dapat menerapkan kebijakan yang mendukung stimulus pertumbuhan ekonomi untuk debitur yang terkena dampak penyebaran COVID-19 termasuk debitur UMKM, dengan tetap memperhatikan prinsip kehati-hatian.

c) Debitur yang terkena dampak penyebaran COVID-19 termasuk debitur UMKM adalah debitur yang mengalami kesulitan untuk memenuhi kewajiban pada Bank karena debitur atau usaha debitur terdampak dari penyebaran COVID-19 baik secara langsung ataupun tidak langsung pada sektor ekonomi antara lain pariwisata, transportasi, perhotelan, perdagangan, pengolahan, pertanian, dan pertambangan.

d) Kebijakan stimulus dimaksud terdiri dari:

1) Penilaian kualitas kredit/pembiayaan/penyediaan dana lain hanya berdasarkan ketepatan pembayaran pokok dan/atau bunga untuk kredit/pembiayaan/penyediaan dana lain dengan plafon s.d Rp10 miliar; dan

2) Peningkatan kualitas kredit/pembiayaan menjadi lancar setelah direstrukturisasi selama masa berlakunya POJK. Ketentuan restrukturisasi ini dapat diterapkan Bank tanpa melihat batasan plafon kredit/pembiayaan atau jenis debitur.

Kerugian lain yang ditimbulkan akibat pengunduran diri karyawan adalah sebagai berikut:

a) Produktivitas kerja akan merosot

b) Perusahaan akan kehilangan tenaga kerja yang potensial yang susah dicari penggantinya

c) Kurang berfungsinya pengelolaan perusahaan Berdasarkan Pasal 61 ayat (1) UU Nomor 13 tahun 2003 tentang ketenagakerjaan, bahwa hubungan kerja atau perjanjian kerja berakhir apabila :

1) Karyawan meninggal dunia

2) Berakhirnya jangka waktu perjanjian kerja

3) Adanya putusan pengadilan dan/atau putusan atau penetapan lembaga penyelesaian perselisihan hubungan industrial yang telah mempunyai kekuatan hukum tetap

4) Adanya keadaan atau kejadian tertentu yang dicantumkan dalam perjanjian kerja, peraturan perusahaan, atau perjanjian kerja bersama yang dapat menyebabkan berakhirnya hubungan kerja."

Artinya, pihak yang mengakhiri hubungan kerja diwajibkan membayar ganti rugi kepada pihak lainnya sebesar upah Karyawan/buruh sampai batas waktu berakhirnya jangka waktu perjanjian kerja, demikian yang disebut dalam Pasal 62 UU Ketenagakerjaan. Adapun perhitungan ganti rugi kepada pihak lainnya yaitu sebesar upah Karyawan/buruh sampai batas waktu berakhirnya jangka waktu perjanjian kerja. Sebelum menghitung berapa jumlah ganti rugi yang harus anda bayar, terlebih dahulu kita perlu memahami definisi upah dan komponen yang ada di dalamnya. Pasal 1 angka 30 UU Ketenagakerjaan bahwa:

"Upah adalah hak Karyawan/buruh yang diterima dan dinyatakan dalam bentuk uang sebagai imbalan dari pengusaha atau pemberi kerja kepada Karyawan/buruh yang ditetapkan dan dibayarkan menurut suatu perjanjian kerja, kesepakatan, atau 
peraturan perundang-undangan, termasuk tunjangan bagi Karyawan/buruh dan keluarganya atas suatu Karyawanan dan/atau jasa yang telah atau akan dilakukan."

Berdasarkan definisi di atas, maka upah terdiri dari hak Karyawan yang dinyatakan dalam bentuk uang ditambah tunjangan. Jika dikaitkan dengan pertanyaan Anda, maka upah adalah gaji pokok termasuk tunjangan yang Anda peroleh setiap bulannya.

\section{Upah $=$ Gaji Pokok + Tunjangan}

Sebagai tambahan penjelasan, hal ini juga sejalan dengan yang dimaksud dengan upah minimummenurut Pasal 1 angka 1 Peraturan Menteri Tenaga Kerja dan Transmigrasi Republik Indonesia Nomor 7 Tahun 2013 tentang Upah Minimum ("Permenaker 7/2013"): "Upah Minimum adalah upah bulanan terendah yang terdiri atas upah pokoktermasuk tunjangan tetap yang ditetapkan oleh gubernur sebagai jaring pengaman."

Anda mengatakan bahwa jika Anda mengundurkan diri, sisa kontrak Anda seharusnya adalah tiga bulan lagi. Dengan demikian, mengacu pada komponen upah dan aturan soal ganti rugi yang kami sebutkan di atas dapat kita simpulkan bahwa jumlah ganti rugi yang wajib Anda bayar yaitu:

\section{Ganti rugi= $3 \times$ (gaji pokok + tunjangan)}

Selanjutnya dalam Pasal 62 Undang-undang Nomor 13 Tahun 2003 tentang Ketenagakerjaan menjelaskan bahwa apabila salah satu pihak dalam perjanjian mengakhiri hubungan kerja sebelum berakhirnya jangka waktu yang ditetapkan dalam perjanjian kerja waktu tertentu, maka pihak yang mengakhiri hubungan kerja diwajibkan membayar ganti rugi kepada pihak lainnya sebesar upah Karyawan/buruh sampai batas waktu berakhirnya jangka waktu perjanjian kerja.

Jadi, seandainya seorang Karyawan/buruh terikat dalam PKWT selama dua tahun , bila baru bekerja dua bulan ingin mengakhiri hubungan-kerja tersebut , maka Karyawan tersebut wajib memberikan ganti rugi kepada pengusaha sebesar 24 bulan (dua tahun) dikurangi dua bulan yaitu 22 bulan dikalikan gaji selama satu bulan (Tri Jata Ayu Pramesti, 2015).

\subsection{Kebijakan Bank dalam Mengenyampingkan Perjanjian Kredit terhadap Debitur yang Terkena Pemutusan Hubungan Kerja}

Wabah Covid-19 sebagai pandemi yang menular secara cepat dan massif (Sufiarina \& Wahyuni, 2020: 1), sehingga pandemi Covid-19 tersebut telah mengakibatkan kesulitan untuk melunasi angsuran kredit atau pembiayaan karena menurunnya penghasilan seharihari (Ubaidillah \& Syah Aji, 2020: 1), seperti pepatah, nasib tak ada seorangpun yang tahu dimasa kedepannya, baik buruknya hanya Sang Pencipta yang Maha Mengetahui.

Omset perusahaan mengalami penurunan secara drastis berdampak terhadap penghasilan yang juga mengalami penurunan secara drastis, sehingga perusahaan terpaksa merumahkan sebagian karyawannya atau bekerja dari rumah bahkan perusahaan dengan terpaksa harus melakukan pemutusan hubungan kerja (Syafrida et al., 2020: 23), yang berdampat pula bagaimana nasib cicilan Kredit Debitur, jika nasabah mengalami Pemutusan Hubungan Kerja (PHK) dari perusahaan tempatnya bekerja ditengah Pandemi COVID-19? Namun, masih ada beberapa opsi yang bisa ditempuh sebagai alternatif sementara.

Ringkasan Eksekutif Peraturan Otoritas Jasa Keuangan Nomor 11/Pojk.03/2020 Tentang Stimulus Perekonomian Nasional Sebagai Kebijakan Countercyclical Dampak Penyebaran Coronavirus Disease 2019 (Pojk Stimulus Dampak Covid-19) ini telah jelas 
mengatur upaya kebijakan apa dan bagaimana terkait bank dan debitur yang terdampak Pandemi COVID-19 ini.

Pada Point 2 Peraturan Otoritas Jasa Keuangan Nomor 11/Pojk.03/2020 Tentang Stimulus Perekonomian Nasional Sebagai Kebijakan Countercyclical Dampak Penyebaran Coronavirus Disease 2019 bahwa:

a) POJK ini berlaku bagi BUK, BUS, UUS, BPR, dan BPRS.

b) Bank dapat menerapkan kebijakan yang mendukung stimulus pertumbuhan ekonomi untuk debitur yang terkena dampak penyebaran COVID-19 termasuk debitur UMKM, dengan tetap memperhatikan prinsip kehati-hatian.

c) Debitur yang terkena dampak penyebaran COVID-19 termasuk debitur UMKM adalah debitur yang mengalami kesulitan untuk memenuhi kewajiban pada Bank karena debitur atau usaha debitur terdampak dari penyebaran COVID-19 baik secara langsung ataupun tidak langsung pada sektor ekonomi antara lain pariwisata, transportasi, perhotelan, perdagangan, pengolahan, pertanian, dan pertambangan.

d) Kebijakan stimulus dimaksud terdiri dari:

1) Penilaian kualitas kredit/pembiayaan/penyediaan dana lain hanya berdasarkan ketepatan pembayaran pokok dan/atau bunga untuk kredit/pembiayaan/penyediaan dana lain dengan plafon s.d Rp10 miliar; dan

2) Peningkatan kualitas kredit/pembiayaan menjadi lancar setelah direstrukturisasi selama masa berlakunya POJK. Ketentuan restrukturisasi ini dapat diterapkan Bank tanpa melihat batasan plafon kredit/pembiayaan atau jenis debitur.

Artinya bahwa Restrukturisasi merupakan kebijakan bank yang dapat memberikan keringanan bagi nasabah atau debitur yang terdampak PHK karena Pandemi COVID-19 ini. Kebijakan ini memang diperuntukan dalam kondisi tertentu, seperti nasabah sedang mengalami pengurangan gaji atau penghasilan menurun.

Untuk cara Restrukturisasi, ini diatur dalam Point 2 Huruf e Peraturan Otoritas Jasa Keuangan Nomor 11/Pojk.03/2020 Tentang Stimulus Perekonomian Nasional Sebagai Kebijakan Countercyclical Dampak Penyebaran Coronavirus Disease 2019. Cara restrukturisasi kredit/pembiayaan dilakukan sebagaimana diatur dalam peraturan OJK mengenai penilaian kualitas aset, antara lain dengan cara:

1) penurunan suku bunga;

2) perpanjangan jangka waktu;

3) pengurangan tunggakan pokok;

4) pengurangan tunggakan bunga;

5) penambahan fasilitas kredit/pembiayaan; dan/atau

6) konversi kredit/pembiayaan menjadi Penyertaan Modal Sementara.

Namun untuk bagaimana nasabah atau debitur yang ingin mendapatkan Restrukturisasi Kredit itu harus mengajukan kepada Bank yang terkait dimana nasabah atau Debitur melakukan perjanjian Kredit. Sebab masing masing Bank memiliki cara pengajuannya masing masing, dimana biasanya ada yang online bebentuk pengisian formulir atau surat permohonan Restrukturisasi Kredit Terdampak Pandemi COVID-19 kemudian dikirimkan melalui email resmi Restrukturisasi Bank terkait. 


\section{Kesimpulan}

Pada dasarnya dalam hukum perdata setiap orang diberi kebebasan untuk membuat perjanjian baik dari segi bentuk maupun muatan, selama tidak melanggar ketentuan perundang-undangan, kesusilaan, kepatutan dalam masyarakat, dampak COVID-19 ini membuat perusahaan melakukan Pemutusan Hubungan Kerja secara terpaksa. Adanya pemutusan hubungan kerja, perusahaan terpaksa harus menyeleksi karyawan untuk tetap atau di keluarkan. Tentu saja hal ini sangat merugikan sekaligus meresahkan. Ini artinya, pihak yang mengakhiri hubungan kerja diwajibkan membayar ganti rugi kepada pihak lainnya sebesar upah Karyawan/buruh sampai batas waktu berakhirnya jangka waktu perjanjian kerja. Adapun perhitungan ganti rugi kepada pihak lainnya yaitu sebesar upah Karyawan/buruh sampai batas waktu berakhirnya jangka waktu perjanjian kerja.

Stimulus Perekonomian Nasional Sebagai Kebijakan Counter Cyclical Dampak Penyebaran Corona Virus Disease-19. Kebijakan bank yang dapat memberikan keringanan bagi nasabah atau debitur yang terdampak PHK karena Pandemi COVID-19 ini disebut sebagai Restrukturisasi. Namun untuk mendapatkan Restrukturisasi, nasabah atau debitur mengajukan kepada Bank yang terkait dimana nasabah atau Debitur melakukan perjanjian Kredit, sebab masing masing Bank memiliki cara pengajuannya masing masing, dimana biasanya ada yang online berbentuk pengisian formulir atau surat permohonan Restrukturisasi Kredit Terdampak Pandemi COVID-19 kemudian dikirimkan melalui email resmi Restrukturisasi Bank terkait.

\section{Daftar Referensi}

\section{Jurnal}

Aminah. (2020). Pengaruh Pandemi Covid 19 Pada Pelaksanaan Perjanjian. Diponegoro Private Law Review, 7(1), 650-656.

Herman, Aliansa, W., Simamora, A. G., \& Chahyani, N. M. (2020). Tinjauan Yuridis Mengenai Dampak COVID-19 Terhadap Pemutusan Hubungan Kerja. Halu Oleo Law Review, 4(2), 157-176. https:/ / doi.org/10.33561/holrev.v4i2.14282

Pesulima, T. L., \& Hetharie, Y. (2020). Perlindungan Hukum Terhadap Keselamatan Kerja Bagi Tenaga Kesehatan Akibat Pandemi Covid-19. SASI, 26(2), 280-285. https:// doi.org/10.47268/sasi.v26i2.307

Randi, Y. (2020). Pandemi Corona sebagai Alasan Pemutusan Hubungan Kerja Pekerja oleh Perusahaan Dikaitkan dengan Undang-Undang Ketenagakerjaan. Yurispruden, 2(1), 119-136.

Sinaga, R. (2018). Peran Pengadilan Hubungan Industrial pada Pengadilan Negeri Padang Kelas Ia dalam Memberikan Kepastian Hukum Terhadap Perkara Pemutusan Hubungan Kerja. Soumatera Law Review, 1(2), 360-379. https:// doi.org/10.22216/soumlaw.v1i2.3528

Sufiarina, \& Wahyuni, S. (2020). Force Majeure dan Notoir Feiten atas Kebijakan PSBB COVID-19. Jurnal Hukum Sasana, 6(1), 1-15. https://doi.org/10.31599/sasana.v6i1.209

Syafrida, Safrizal, \& Suryani, R. (2020). Pemutusan Hubungan Kerja Masa Pandemi Covid19 Perusahaan Terancam Dapat Dipailitkan. Pamulang Law Review, 3(1), 19-30.

Ubaidillah, M., \& Syah Aji, R. H. (2020). Tinjauan atas Implementasi Perpanjangan Masa 
Angsuran untuk Pembiayaan Di Bank Syariah pada Situasi Pandemi Covid-19. Islamic Banking: Jurnal Pemikiran Dan Pengembangan Perbankan Syariah, 6(1), 1-16. https:// doi.org/10.36908/isbank.v6i1.159

Buku

Ferianto, \& Darmanto. (2009). Himpunan Putusan Mahkamah Agung Dalam Pekara HPI. Jakarta: Raja Grafindo Persada.

Husni, L. (2010). Hukum Ketenagakerjaan Indonesia. Jakarta: Raja Grafindo Persada.

Ibrahim, J. (2006). Teori dan Metode Penelitian Hukum Normatif. Malang: Bayu Media Publishing.

Rusli, H. (2004). Hukum Ketenagakerjaan 2003. Jakarta: Ghazali Indonesia.

\section{Online/World Wide Web}

Shinta W Kamdani. (n.d.). Alasan Pengusaha Terpaksa PHK Karyawan di Tengah Pandemi Corona. Retrieved May 16, 2020, from https://www.google.com/amp/s/m.merdeka.com/amp/uang/alasan-pengusahaterpaksa-phk-karyawan-di-tengah-pandemi-corona.html

Tri Jata Ayu Pramesti. (n.d.). Besaran Jumlah Ganti Rugi Jika Resign Sebelum Kontrak Selesai. Retrieved November 28, 2019, from https://m.hukumonline.com/klinik/detail/ulasan/lt5498cc37a2958/besaran-jumlahganti-rugi-jika-resign-sebelum-kontrak-s elesai/ 